\title{
Javanese cosmology: Symbolic transformation of names in Javanese novels
}

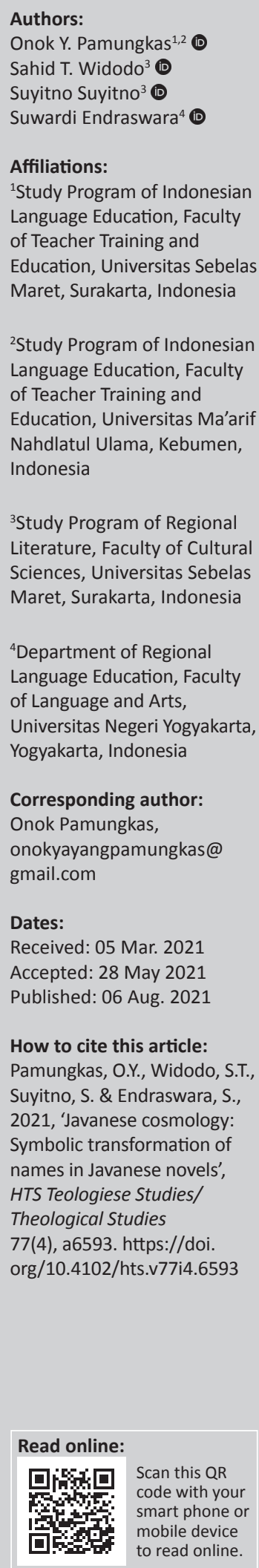

In the past, no research has been found on onomastics from a mystical perspective in literature. This study investigated onomastics in the tetralogy of novels by Ki Padmasusastra (after this referred to as TNKP). The main point of view is the meaning of Javanese cosmology. Qualitative methods are used as research guidelines. The primary data are four Javanese novels. Hermeneutic techniques and content analysis are applied to analytical strategies. The results showed that the onomastics in TNKP are symbols of Javanese cosmology. This element of Javanese cosmology has transformed onomastics through three things: the novel title, figure's name and location name. The symbolisation of the onomastic is implicit because it is wrapped in the aesthetics of the literary language. The name structure of each onomastic subsection has no clear meaning because the name element is intended for the sense of 'the other'. Names have an explicit function, namely as hypertextual fragments of symbols that transcend the narrative text structure. An important implication of this investigation is that onomastics can promote the transdisciplinary aspects of religion in international theology in the study of narrative texts. The cosmological transformation of Java can be reflected in various parts of culture, including in novels. TNKP is a cross-disciplinary meeting: fiction, linguistics, mystical, social, cultural and philosophical, contributing to further theological studies.

Contribution: This article contributes to the purpose of HTS Teologiese Studies/Theological Studies to promote the transdisciplinary aspects of religious studies in the international theological arena of hermeneutic and philosophical studies behind the narrative text.

Keywords: onomastic; anthroponymy; toponymy; Javanese cosmology; Javanese mysticism; Javanese novels.

\section{Introduction}

The name is an important element for information in the field of scientific discovery. Bertrand Russell (1918:523) once said that a name is the only word used to describe something. Names are one media that record various cultural aspects (Mbarachi \& Igwenyi 2018; Sabet \& Zhang 2020; Widodo 2015). We can glean important information about society's history, culture and development over time through its name. A name can symbolise ideology and social identity that continue to develop (Chaemsaithong 2019). Therefore, research on names becomes very important in a broad context.

Research efforts on names have attracted the interest of several experts. Most of them see names from a personal name standpoint (see, e.g. Algeo \& Algeo 2000; Sabet \& Zhang 2020; Widodo 2015). The field of study also extends to aspects of place names (Chiwanga \& Mkiramweni 2019), title names (Agyekum 2006; Ennin \& Nkansah 2016), brand names (Danesi 2011; Hernández 2013), account names in the digital world (Hassa 2012) and even names related to transgender people (Obasi et al. 2019). However, unfortunately, the determination of the terms of the existing name is still in the context of social reality, focusing on the social paradigm. It is still open to expanding the context of names in other fields, such as the context of fictional literature. After all, literature often offers imaginary realities that transcend the boundaries of rationality. This also often results in literary truths transcending social reality. The author's worldview of the various traditions of the world will provide a wealth of important information for developing advanced onomastic theories, especially concerning the form and meaning of the name.

In Java, ${ }^{1}$ there are four novels by Ki Padmasusastra known as mystical novels. The four novels are Serat Pethikan Saking Kabar Angin, Serat Rangsang Tuban, Serat Prabangkara and Serat Kandha Bumi

1.Java is a tribe in Indonesia. They inhabit especially the provinces of Central Java, Yogyakarta and East Java. Javanese people are also scattered in various islands in Indonesia, even abroad. However (Magnis-Suseno 1984:11), the Javanese are the original inhabitants of Java, who speak Javanese. 
(called TNKP). The author is known as a mystic (Quinn 1982). TNKP was written over 23 years, between 1901 and 1924. The four stories in TNKP are inseparable because they have symbolic structural links (Wibowo 2016). Ki Padmasusastra wrote during the Dutch colonial period in Indonesia. Simultaneously, the writing process also takes place during Javanese socio-cultural conditions that are still thick with Hindu, Buddhist and Islamic syncretism, similar to Balinese tradition (Lifintseva \& Tourko 2018). TNKP is a mystical novel because the storyline depicts many mysterious events (Quinn 1982). It is strongly suspected that the novel's claims and esoteric author's impact on the storyline and its naming.

Aspects of the name in TNKP are very important to the investigation. From one point of view, through the mystic perspective of the author, important information will be obtained about the history, culture and syncretism of religion and mystical traditions in Javanese society. From another point of view, there will be important details about the transformation model of a writer's mystical, spiritual and theological values through literary works. In some forms, text transformation is often through the process of hypertextuality. For this reason, this study tried to understand the meaning of naming from two different perspectives: (1) the nature of language in text transformation and (2) name function in literature. This research is an effort to develop advanced onomastic research on an international scale. It is hoped that understanding the meaning of name elements in TNKP can help open up insights and culture through literary works.

\section{Theoretical framework}

This research is an interdisciplinary study involving various fields of science: literature, onomastics, languages, culture, theology and philosophy. Therefore, some relevant theories will be displayed as a reference for discussion. The approaches considered the most dominant used in discussions that are onomastics, Javanese cosmology and hypertextuality. Each will be detailed as follows.

\section{Onomastics}

Onomastics is a field that studies names (Algeo 1973; Algeo \& Algeo 2000; Van Langendonck 2007; Widodo 2015), and this field can be viewed from a variety of perspectives. This study includes linguistic studies related to certain community cultures. The main purpose is to label names linguistically from a cultural perspective. By name, we can identify a person's origin (Widodo 2015). In other words, naming is a cultural construct to identify a person, object or other entity by applying artistic strategies in a particular society through language. Naming is a relationship between two parties' language and culture (Algeo \& Algeo 2000; Sabet \& Zhang 2020; Widodo 2015).

Onomastics also includes a discussion of names in the second world, such as myth, literature, film and the supernatural world (Algeo \& Algeo 2000). In addition, several functions appeared in the literary world (Chaemsaithong
2019). In academic studies, onomastic studies will help reveal the artistic picture of the world through fiction. It reflects the author's ideas about the different areas of onomastic space, the principles of human nomenclature and everything around them. Through the author's artistic awareness, social portraits of names are often transformed into fictional worlds with a specific purpose.

\section{Javanese cosmology}

Cosmology is rooted in the word cosmos, which means order and harmony. The opposite of cosmos is chaos, which means disturbance (Sagan 1996; Wyatt 2005). Cosmological studies examine the fundamental nature of the universe. In turn, cosmology has become an important part of the philosophical intersection, namely philosophy of physics or natural philosophy (Kattsoff 1996:240). Three important points in the study of cosmology are as follows: (1) the study of philosophy on the main terms contained in physics, (2) prepositions contained in physics as the science of the universe and (3) philosophy of physics concerning the investigation of the composition of physics as a science. In essence, the scope of cosmology is the study of problems of physics, not problems in physics. In turn, cosmology gained a clearer meaning in discussing the existence of the One, which is the essence of the universe.

Meanwhile, Javanese cosmology is the Javanese philosophy of life about the deepest nature of the cosmos (Magnis-Suseno 1984; Mulder 2001; Simuh 1999). The Javanese think that the universe is God's faith. In other words, the universe, man and God are a single element. Therefore, they think that the nature of human life is manunggaling kawula-Gusti, which is about the nature of man's unification with God (Mulder 2001; Simuh 1999; Waston 2018). As a result, all entities are the inseparable structured totality. The knowledge of God's faith puts the universe as a macrocosm, human beings in their position as a microcosm. Macro-microcosm has the same core elements: water, fire, earth and air. Based on the likeness of these core elements, harmonisation between macrocosm and microcosm must always be maintained. It is a view of Javanese life that defines the cosmos as a sacred entity.

Knowledge of the sacredness of the cosmos has implications for ethical behaviour (Almirzanah 2020; Magnis-Suseno 1984; Mulder 2001; Waston 2018). Human life follows the laws of nature to maintain balance. This understanding of the nature of life allows humans to find self-awareness through their inner self. People will also increasingly understand their origins through their minds, namely God (Magnis-Suseno 1984). Reflection on the nature of life in the universe is man's efforts to define human life in the cosmos. The nature of life always has a relationship between the empirical and the meta-empirical. In turn, the essence of humanity's final destiny is to return to its origin (God). Thus, Javanese people viewed the universe as a sacred totality. 


\section{Hypertextuality}

Hypertextuality is a science that studies the relationship between one text and another (Cicconi 2012; Genette 1997; Sandbothe 2017). The text, in this case, has a broader meaning. Text is not only in the form of a series of letters, but traditions, artefacts, events, beliefs, ideas, objects and other cultural ideas are also a form of 'text'. Hypertextuality is part of trans sexuality, which is 'everything that defines a text in a relationship, whether clear or hidden, with other text' (Genette 1997). Hypertextual relationships are unsorted structures that allow the reader to create interpretations (Cicconi 2012). Hypertextual logic not only reconstructs criteria through information exchange but also dismantles textual paradigm solidity and textual analysis (Sandbothe 2017). In principle, hypertextuality refers to any relationship that unites text $\mathrm{B}$ (referred to as hypertext) to the previous text A (referred to as hypotext). According to Genette (1997), the relationship can take many forms, including imitation, parody, satire, development and pastiche (transformation of other formats).

Genette (1997:5) states two possible links between hypotext and hypertext. Firstly, hypertext is the transformation of the hypotext. That is, turning the old text into a new shape. Secondly, hypertext is an imitation of the hypotext. This imitation is an indirect transformation process. The imitation process follows a certain style but does not follow a series of actions. Imitation is usually an affinity and thematic form. Also, the transformation of the hypotext into hypertext can occur in the form of reduction and strengthening. Deductions include removing certain sections, cutting and subtraction (Allen 2000:109). Reinforcement provides an extension, contamination and expansion process. Support in the hypertext can be in the form of revealing things that are missing or not present in the hypotext.

In turn, hypertext is a combination of 'real' and 'unrealistic', which in Baudrillard's (1988) terms is 'simulacra'. Simulacra is a deceptive depiction of representation. For Baudrillard, simulacra take us into a circular world because signs are not interchangeable with meaning but only for other purposes. As a result, simulation is a real active replacement process. Simulacra's procreation led to Baudrillard's view of a new era of simulation, meaning all references had been removed. Thus, the difference between real and symbolic has collapsed. Therefore, it is not easy to distinguish between real and fictional. What emerges is more than just a symbol of actual reality.

\section{Materials and methods}

This study seeks to uncover and provide critical arguments of Javanese cosmology from an onomastics perspective. The focus of the investigation is the author's form and motive on the symbolic transformation that occurred in the realm of Javanese literary works. Various onomastics models are considered strategies for transforming text
TABLE 1: Data for four novels by Ki Padmasusastra.

\begin{tabular}{lcc}
\hline Novel title & Publication year & Catalog code \\
\hline Serat Pethikan Saking Kabar Angin (SPSKA) & 1901 & $1901-315, \# 39$ \\
Serat Rangsang Tuban (SRT) & 1912 & $1912, \# 516$ \\
Serat Prabangkara (SP) & 1921 & $1921, \# 43$ \\
Serat Kandha Bumi (SKB) & 1924 & $1924, \# 112$ \\
\hline
\end{tabular}

from Javanese cosmological text to name text in fictional literature. As a result, this study is an interdisciplinary study of literature, onomastics, languages, culture, theology and philosophy. Therefore, qualitative methods of content analysis and hermeneutic were chosen because it is considered capable of providing a comprehensive explanation of the interpretation of the text (Creswell 2007; Krippendorff 2010; Ricoeur 2016).

The research object is fiction literature published online on https: / www.sastra.org, managed by Yayasan Sastra Lestari, Surakarta, Central Java, Indonesia. The research data sources are four novels by Ki Padmasusastra, detailed in Table 1.

These research data are in the form of names that implicitly contain the meaning of Javanese cosmology in TNKP. The data were obtained from critical, thorough and in-depth readings of four TNKP novels. Name elements are classified by category title name, character name and location name. Three name categories were chosen because they meant Javanese cosmological symbols. The results of the classification of names tested validity using relevant theories (Creswell 2007). Once the encoding is confirmed valid, the name texts are interpreted based on two things: (1) the nature of the language in literary hypertextuality and (2) the meaning of name philosophy in Javanese cultural perspective. Efforts to interpret the meaning of the name are made carefully by paying attention to the relationship between the text mark and the Javanese cosmological meaning. The results of the study were verified to formulate an interim conclusion. After a careful verification process, the last is the conclusion of the research.

\section{Result}

For the sake of clarity, this section is presented in chronological order about the process of transformation of Javanese cosmological elements in TNKP. As previously stated, Javanese cosmological elements consist of water, fire, earth and air. In Javanese belief, macro-microcosm is the embodiment of God's substance (Mulder 2001; Simuh 1999). The four elements of Javanese cosmology are found similar meanings to the name symbols in TNKP. The form of Javanese cosmology transformation into literature is found in three types, namely (1) through the element of name in the title of the novel, (2) through elements of the character's name (anthroponymy) and (3) through the naming of the territory (toponymy). The details will be explained as follows.

\section{Through element name in a novel title}

The concept of transformation of Javanese cosmological symbols does appear planned by the author. The transformation of Javanese cosmological symbols begins 
with the naming model of each novel's title. In its full meaning, Serat Pethikan Saking Kabar Angin, meaning 'Quotation Letter from the Wind'; Serat Rangsang Tuban, meaning 'Water Excitatory Letter'; Serat Prabangkara, meaning 'Letter of Fire' and Serat Kandha Bumi, meaning 'Letter of the Earth'. However, if the overall meaning of the title is analysed, there has been no clarity of the relationship between the four novels. Therefore, the word elements in each title will be sorted so that the symbol function will be clearer.

Based on a more focused analysis on the separation of name elements in the title, the following facts are generated: (1) Serat Kabar Angin, in which angin means wind; (2) Serat Rangsang Tuban, in which tuban means water; (3) Serat Prabangkara, in which prabangkara means fire and (4) Serat Kandha Bumi, in which bumi means land.

The symbolisation of Javanese cosmological elements in the novel's title is the smallest step taken by the author. In a general theory, the title of the story will give an idea of the fictional storyline. However, in this case, there is no connection between the novel title and the narrative plot. From one perspective, especially in the history of Javanese literature, such a model has never been found in novels in general. On another view, in onomastic studies, even in the wider literary field, there has never been a particular symbolisation placed in the title of a novel. Therefore, the symbolisation of Javanese cosmology in the title KPNT will provide novelty, both in literature and onomastics in general.

\section{Through the name of the figures element (Anthroponymy)}

The transformation of Javanese cosmological elements can then be traced to the names of figures in KPNT. Based on the data obtained, each figure's part has a similar meaning to the aspect of Javanese cosmology. The sense in the figure's name also corresponds to the sense in the novel title element. Detailed data on this anthroponymy are visualised in Table 2.

In Table 2, the figure's name in bold letters is the sign about the symbols of the four elements of nature. There is no description of the nature of the figures related to the philosophy of water, earth, fire and air. Moreover, there is also no relationship between the meaning of the character's name (anthroponymy) and the nature of the character. The figure's character is very natural, namely with the protagonist's nature, antagonist and tritagonist as the novel generally. These findings differ from some experts' findings in various studies that the figure's character corresponds to the name (see, e.g. Gibka \& Coates 2018; Hramova 2016). The incompatibility between the name and the character corroborates the allegation that the author only uses the elements of the figure's name in the KPNT to strengthen the symbolisation of Javanese cosmology. The author's purpose becomes clearer as different figures are given similarly meaningful names, varied through synonyms of the word archaic or ancient.

On the one hand, the variety of the word archaic synonyms will make it difficult to detect meaning. On the other hand,
TABLE 2: Javanese cosmology in people's names.

\begin{tabular}{|c|c|c|c|}
\hline \multirow{2}{*}{$\begin{array}{l}\text { Novel name } \\
\text { Serat Kabar } \\
\text { Angin }\end{array}$} & \multicolumn{2}{|c|}{ Figure name } & \multirow{2}{*}{$\begin{array}{l}\text { The meaning of } \\
\text { the player name } \\
\text { element } \\
\text { Wind }\end{array}$} \\
\hline & $\begin{array}{l}\text { - Dèwi Angin-angin } \\
\text { - SindhungAliwawar } \\
\text { - Dèwi Maruti } \\
\text { - Pangeran Pracondha } \\
\text { - Jaka Erawana } \\
\text { - Jadèn Prakêmpa } \\
\text { - Dèwayu Bantarangin } \\
\text { - Radèn Uswasa } \\
\text { - Radèn Timur } \\
\text { - Begawan Anila }\end{array}$ & $\begin{array}{l}\text { - Adipati Tanggulangin } \\
\text { - Samirana } \\
\text { - Dewi Sumilir } \\
\text { - Jaka Pôncawora } \\
\text { - Rayubajra } \\
\text { - Prabu Barawatkatiga } \\
\text { - Raden Bajrapati } \\
\text { - Jaka Urur } \\
\text { - Apatih Bajrarumung } \\
\text { - Adipati Sindhungkara }\end{array}$ & \\
\hline $\begin{array}{l}\text { Serat } \\
\text { Rangsang } \\
\text { Tuban }\end{array}$ & $\begin{array}{l}\text { - Prabu Hèrtambang } \\
\text { - Udakawimba } \\
\text { - Raden Toyatuli } \\
\text { - Toyamarta } \\
\text { - Warihkusuma }\end{array}$ & $\begin{array}{l}\text { - Sindupati } \\
\text { - Endhang Wrêsti } \\
\text { - Dèwi Wayi } \\
\text { - Jalasêngara } \\
\text { - Umbul Mudal }\end{array}$ & Water \\
\hline $\begin{array}{l}\text { Serat } \\
\text { Prabangkara }\end{array}$ & $\begin{array}{l}\text { - Ôndakara } \\
\text { - Ôndapawaka } \\
\text { - Rara Apyu } \\
\text { - Anala } \\
\text { - Prabangkara } \\
\text { - Prabanggêni }\end{array}$ & $\begin{array}{l}\text { - Pêdhakbrama } \\
\text { - Jaksapawaka } \\
\text { - Mrêtyubeya } \\
\text { - Gêniroga } \\
\text { - Gêniyara } \\
\text { - Bramarkata }\end{array}$ & Fire \\
\hline $\begin{array}{l}\text { Serat Kondha } \\
\text { Bumi }\end{array}$ & $\begin{array}{l}\text { - Kyai Rasatala } \\
\text { - Kismawati } \\
\text { - Endhang Siti Pasir } \\
\text { - Puthut Sapartitala } \\
\text { - Dèwi Pratiwi }\end{array}$ & $\begin{array}{l}\text { - Patih Janaloka } \\
\text { - Prabu Mangkubumi } \\
\text { - Maetala } \\
\text { - Umbul Jaga } \\
\text { - Mandhala } \\
\text { - Prabu Bumi Padha }\end{array}$ & Land \\
\hline
\end{tabular}

repeated synonyms of the word often resulted in a mystical nuance increasingly deeply entrenched within the KPNT. Thus, the symbolisation of anthroponymy in the KPNT is for mystical purposes, not for any other purpose.

Anthroponymy in KPNT is a linguistic mark used to label figures. The nature of anthroponymy in KPNT is essential for practical mystical reasons. The unnatural meaning of the figures shows the onomastic boundaries between the real and the fictional. This kind of name attribute can also be referred to as a 'bodyless' name. That is, the name serves not for 'body or personal' prayer but other purposes. That fact means the name is taken separately from the reference. Thus, literature creates an alternative space for reality, where name references are always fictional. In other words, the term itself becomes a textual fragment not to reveal the truth about the character but to follow certain connotations.

\section{Through the naming of regions (Toponymy)}

The next form of Javanese cosmological symbol transformation is a regional name (toponymy). Based on the data obtained, the element of the location name in the KPNT contains the meaning of the symbol of the four natural elements. Data on cosmological toponymy conform to the title and anthroponymy in the novel. Visualisations about toponymy can be seen in Table 3 .

The bold location names in the table are a sign of the four natural elements. Various elements of toponymy are created by selecting synonyms for words that fit the theme. Indeed, not all locations have the meaning of four elements of nature. For example, in SP, there is only one toponymy that means the element of fire. However, at least it has fulfilled the author's goal in transforming Javanese cosmological symbols through toponymy. The symbol is displayed in the form of toponymy state, kingdom, village and mountain. 
TABLE 3: Meaning of place names.

\begin{tabular}{lll}
\hline TABLE 3: Meaning of place names. & Meaning of character names \\
\hline SKA & Place name & Wind \\
SPSKA & $\begin{array}{l}\text { Nagari Marutamanda } \\
\text { Tanah Ngatasangin } \\
\text { Redi Tanggulangin } \\
\text { Wukir Saribit }\end{array}$ & Water \\
& $\begin{array}{l}\text { Nagari Tuban } \\
\text { Dukuh Mudal } \\
\text { Nagari Banyubiru } \\
\text { Nagari Tirtakandhas }\end{array}$ & \\
SP & $\begin{array}{l}\text { Dhusun Gumantar } \\
\text { SKB }\end{array}$ & Padhukuhan Maetala \\
& $\begin{array}{l}\text { Lêbu Pasir } \\
\text { Negara Bantala Rengka } \\
\text { Kerajaan Bumi Dhasar }\end{array}$ & Land \\
\end{tabular}

Toponymy in TNKP was still influenced by socio-graphic conditions in Java when the novel was created. Toponymy imagination is still fundamental to the image of the Javanese landscape, with its simplicity of nature and culture. Images of palaces, rural and mountain landscapes are still words in the literary text. However, because of the design work, the name of the region in TNKP has an unnatural meaning. Toponymy in TNKP represents a fictional world that attaches more importance to the author's aesthetics, conceptual and interests. Toponymy in TNKP is not based on facts (compare Sexton 2017; Trexler 2015) but only manipulating the author's language to represent Javanese cosmological symbols. Literary discourses like this, in turn, are part of theological and cultural practices in the wider region.

\section{Discussion}

Onomastics in TNKP is the result of the transformation of Javanese cosmological symbols. The four core elements of the cosmos are converted into literary texts. Javanese cosmology as the text of 'view of life' transforms into the text of 'name' in fiction. In the perspective of hypertextuality (Allen 2000; Genette 1997), Javanese cosmology is hypotext, whilst onomastic as the new text is hypertext. The transformation process uses an imitation (indirect) model. Imitation forms apply affinity and thematic structure. In the process of transformation, TNKP only makes imitations of hypotext (Javanese cosmology). However, TNKP as hypertext undergoes many forms, namely the name of the novel title, figure's name (anthroponymy) and regional name (toponymy). The transformation process moves towards expansion, expansion and multi-contextual contamination (compare Allen 2000:110).

The names in TNKP are a form of inter-text transformation. The language structure is circular because each sign in the text does not exchange meanings but for other signs. The signs about anthroponymy and toponymy represent the inner meaning and other meanings, namely about Javanese cosmology. The transformation of onomastic symbols, in this case, has destroyed the logic of meaning in the semantic system. There is no longer any language logic because there is a game of language, code and sign. The onomastic text function inside the TNKP is just a surface game. The substance of onomastic meaning is no longer in the circle of words, phrases, clauses, sentences, even novel structures, but on the contrary, meaning develops beyond the boundaries of such structures. It creates extreme direction towards multireference (compare, Baudrillard 1988; Tiupa 2007). As a result, the meaning of literature is completely blurred because of the principle of hypertext function, which allows arbitrary literary intervention. At the same time, it is a productive alternative for authors to realise the creativity of symbols in various ways.

The transformation of Javanese cosmological symbols in TNKP is also inseparable from the socio-cultural influence of the author. This is because the author lives and grows in the social situation of Javanese people in the government system of Surakarta kingdom, which is still active. The social condition of traditional Javanese people is still strong about spiritual and mystical culture (Mulder 2001; Waston 2018). They still regard the cosmos (universe) as a network of sacred structures. Ki Padmasusastra permeates the understanding of the sacredness of the universe in life to become a core value in literary symbolisation. The view of the sacredness of nature provides a means of constructing the complexity of symbols, even when reality itself has no simple references.

The reference to the onomastic symbol in the TNKP means the Javanese cosmological symbol; Javanese cosmology refers to mystical beliefs about the nature of God's immanence (Mulder 2001; Simuh 1999). The mystical view of Javanese society about cosmology, ontologically, teaches harmonising the relationship between humans, nature and God. Javanese mysticism's insight into cosmology reaches its peak in the belief about manunggaling kawula-Gusti, namely about the nature of the union of man with God (Mulder 2001; Simuh 1999; Waston 2018). For this reason, it is strongly suspected that the transformation of the Javanese cosmology within the KPNT was one of the ways for a writer to go on a mystical path as Kourie (2016) says that the path to mystique can indeed be done in various ways. Symbolisation is a literary way of speaking (Benczes 2013; Mun 2017). Thus, Ki Padmasusastra, as a mystical writer, determined his way to get close to God. As a result, TNKP combines fiction, mystique, culture and reality in a narrative text.

\section{Conclusion}

The name in TNKP is not just a term but reflects the universality of Javanese literature with a philosophical spirit. The research findings show that naming in TNKP is not an act of arbitrary labelling but rather an act of building theological structures in literary works. The names in TNKP are symbols of Javanese cosmology. The four natural elements (wind, water, fire and earth) included in the aesthetics of the fictional language are symbols of Javanese cosmology. The transformation of these four elements of Javanese cosmology represents the driving force in humans and turns it into the spirit of Javanese life. The Javanese cosmological view is about harmonising relations as a kind of union between a man and God, culminating in the Javanese philosophy of life. The four 
elements of cosmology are represented onomastically in three ways: novel titles, character names and region names. Name references are implied because they are wrapped in the aesthetics of literary language. The name structure in each name element does not have a clear meaning because the meaning of the name element aims at the meaning of 'other'. As a result, names in fiction lose certain attributes. The name has an unknown function, namely as a hypertextual fragment of a symbol that transcends the narrative text structure.

An important implication of this research is that onomastics can promote the transdisciplinary aspects of religion in the international theological arena in the study of narrative texts. The mystical transformation of a writer can be reflected in various parts of culture, including the novel. The TNKP is a cross-disciplinary meeting: fiction, linguistics, metaphysics, social, cultural and philosophical, contributing to advanced theological studies. In this sense, the onomastic approach captures the dynamic and deep-rooted choice of names and mystical preferences. The onomastic symbolisation of literature creates an alternative reality in a metaphysical dimension. Thus, spirituality and science play an important role in the world of fiction. However, this investigation is still limited to TNKP. Therefore, regarding further investigations, the results are unclear if the onomastics in TNKP are compared to Ki Padmasusastra's other works.

\section{Acknowledgements}

The authors would like to thank the Lembaga Pengelola Dana Pendidikan (LPDP) for providing this research funding support.

\section{Competing interests}

The authors declare that they have no financial or personal relationships that may have inappropriately influenced them in writing this article.

\section{Authors' contributions}

All authors contributed equally to this work.

\section{Ethical considerations}

Ethical clearance to conduct the study was obtained from Universitas Sebelas Maret (clearance number: 2801/ UN27.02/DP/2020).

\section{Funding information}

This research was funded by the Lembaga Pengelola Dana Pendidikan (LPDP).

\section{Data availability}

Data sharing is not applicable to this article as no new data were created or analysed in this study.

\section{Disclaimer}

The views and opinions expressed in this article are those of the authors and do not necessarily reflect the official policy or position of any affiliated agency of the authors.

\section{References}

Agyekum, K.K., 2006, 'The sociolinguistics of Akan personal names', Nordic Journal of African Studies 15(2), 206-235.

Algeo, J., 1973, On defining the proper name, University of Florida Press, Gainesville, FL.

Algeo, J. \& Algeo, K., 2000, 'Onomastics as an interdisciplinary study', Names 48(3-4), 265-274. https://doi.org/10.1179/nam.2000.48.3-4.265

Allen, G., 2000, Intertextuality, Routledge, London.

Almirzanah, S., 2020, 'God, humanity and nature: Cosmology in islamic spirituality', HTS Teologiese Studies/Theological Studies 76(1), 1-10. https://doi.org/10.4102/ hts.v76i1.6130

Baudrillard, J., 1988, Simulacra and simulations, pp. 166-184, Stanford University Press, Stanford, CA.

Benczes, R., 2013, 'The role of alliteration and rhyme in novel metaphorical and metonymical compounds', Metaphor and Symbol 28(3), 167-184. https://doi.org/ 10.1080/10926488.2013.797728

Chaemsaithong, K., 2019, 'Names and identities in courtroom narratives', Names 67(4), 185-198. https://doi.org/10.1080/00277738.2018.1490515

Chiwanga, F.E. \& Mkiramweni, N.P., 2019, 'Ethno-ornithology and onomastics in the Natta community, Serengeti district, Tanzania', Heliyon 5(10), e02525. https://doi. org/10.1016/j.heliyon.2019.e02525

Cicconi, S., 2012, 'Hypertextuality', in S. Inkinen (ed.), Mediapolis, pp. 21-43, De Gruyter, Berlin.

Creswell, J.W., 2007, Qualitative inquiry \& research design: Choosing among five approaches, Sage, Thousand Oaks, CA.

Danesi, M., 2011, 'What's in a brand name? A note on the onomastics of brand naming', Names 59, 175-185. https://doi.org/10.1179/002777311X13082331190119

Ennin, T.P. \& Nkansah, N.B., 2016, 'A literary anthroponomastics of three selected African novels: A cross-cultural perspective', International Journal of Society, Culture \& Language 4, 69-79.

Genette, G., 1997, Palimpsests: Literature in second degree, transl. C. Newman \& C. Doubinsky (ed.), University of Nebraska Press, Lincoln, OR.

Gibka, M.K. \& Coates, R., 2018, 'Literary onomastic theory - An introduction literary onomastic theory - An introduction', Journal of the International Council of Onomastic Sciences 53(1), 7-10. https://doi.org/10.34158/ONOMA.53/2018/1

Hassa, S., 2012, 'Projecting, exposing, revealing self in the digital world: Usernames as a social practice in a Moroccan Chatroom', Names 60(4), 201-209. https://doi. org/10.1179/0027773812Z.00000000031

Hernández, L.P., 2013, 'A pragmatic-cognitive approach to brand names: A case study of Rioja wine brands', Names 61(1), 33-46. https://doi.org/10.1179/002777381 $2 Z .00000000038$

Hramova, T., 2016, "'Poetry in the raw": Defining and translating proper names in literature', Procedia - Social and Behavioral Sciences 231(May), 159-164. https:// doi.org/10.1016/j.sbspro.2016.09.086

Kattsoff, L., 1996, Pengantar Filsafat, S. Soemargono (ed.), Tiara Wacana, Yogyakarta.

Kourie, C., 2016, 'The way of the mystic: The sanjuanist stages of the spiritual path', HTS Teologiese Studies / Theological Studies 72(4), 1-11. https://doi.org/10.4102/ HTS Teologiese
hts.v72i 4.3258

Krippendorff, K.H., 2010, Content analysis: An introduction to its methodology, 2nd edn., Sage, Thousand Oaks, CA.

Lifintseva, T. \& Tourko, D., 2018, 'The strategy of ontological negativity in Meister Eckhart's metaphysics and in philosophical traditions of India', Religions 9(12) 386. https://doi.org/10.3390/rel9120386

Magnis-Suseno, F., 1984, Etika Jawa, PT Gramedia, Jakarta.

Mbarachi, C.S. \& Igwenyi, E., 2018, 'Language, identity and the cultural context of names in selected Nigerian novels', International Journal of Language and Literature 6(1), 29-37. https://doi.org/10.15640/ijll.v6n1a5

Mulder, N., 2001, Mistisisme Jawa, LKiS, Yogyakarta.

Mun, Y.S., 2017, 'Elderly suicide in Korean literature: A reflection on short- and medium-length novels', HTS Teologiese Studies/Theological Studies 73(3), 1-8. https://doi.org/10.4102/hts.v73i3.4522

Obasi, S.N., Mocarski, R., Holt, N., Hope, D.A. \& Woodruff, N., 2019, 'Renaming me: Assessing the influence of gender identity on name selection', Names 67(4) 199-211. https://doi.org/10.1080/00277738.2018.1536188

Padmasusastra, K., 1901, Serat Pêthikan Saking Kabar Angin, Yayasan Sastra Lestari, Surakarta.

Padmasusastra, K., 1912,, Serat Rangsang Tuban, Yayasan Sastra Lestari, Surakarta.

Padmasusastra, K., 1921, Serat Prabangkara, Yayasan Sastra Lestari, Surakarta.

Padmasusastra, K., 1924, Serat Kôndha Bumi, Yayasan Sastra Lestari, Surakarta.

Quinn, G., 1982, 'Padmasusastra's Rangsang Tuban: A Javanese Kabatinan novel', Archipel 24(Januari), 161-187. https://doi.org/10.3406/arch.1982.1777 
Ricoeur, P., 2016, 'Hermeneutics and the human sciences', in J.B. Thompson (ed.) Nucleic acids research, Classics e, Cambridge University Press, Cambridge.

Russell, B., 1918, 'The philosophy of logical atomism', The Monist 28(4), 495-527. https://doi.org/10.4324/9780203864777

Sabet, P.G.P. \& Zhang, G., 2020, 'First names in social and ethnic contexts: A socioonomastic approach', Language and Communication 70, 1-12. https://doi. org/10.1016/j.langcom.2019.09.004

Sagan, C., 1996, Cosmos, Random House, New York, NY.

Sandbothe, M., 2017, 'Interactivity - Hypertextuality - Transversality. A mediaphilosophical analysis of the Internet', HERMES - Journal of Language and
Communication in Business 13(24), 81. https://doi.org/10.7146/hjlcb.v13i24.25570

Sexton, M., 2017, 'Tropic of Orange, Los Angeles, and the Anthropocene imagination', Concentric: Literary and Cultural Studies 43(1), 13-32. https://doi.org/10.6240/ concentric.lit.2017.43.1.02

Simuh, S., 1999, Sufisme Jawa: Transformasi Tasawuf Islam ke Mistik Jawa, Yayasan Bentang Budaya, Yogyakarta.
Tiupa, V., 2007, 'Mytho-tectonics of the Petersburgian hypertext of Russian literature', Russian Literature 62(1), 99-112. https://doi.org/10.1016/j.ruslit.2007.07.007

Trexler, A., 2015, Anthropocene fictions: The novel in a time of climate change, University of Virginia Press, Charlottesville and London.

Van Langendonck, W., 2007, Theory and typology of proper names, Walter de Gruyter, Berlin.

Waston, W., 2018, 'Building peace through mystic philosophy: Study on the role of Sunan Kalijaga in Java', Indonesian Journal of Islam and Muslim Societies 8(2), 281-308. https://doi.org/10.18326/ijims.v8i2.281-308

Wibowo, P.A.W., 2016, Kajian Stilistika Karya-Karya Sastra Ki Padmasusastra Perspektif Kritik Holistik, Universitas Sebelas Maret, Surakarta.

Widodo, S.T., 2015, 'Personal names as an inter-ethnic model of acculturation in Indonesia', Asian Journal of Social Sciences \& Humanities 4(1), 126-133.

Wyatt, N., 2005, The mythic mind: Essays on cosmology and religion in Ugaritic and Old Testament literature, Equinox Publishing Ltd., London. 